\title{
PEMANFAATAN TUNA SIRIP BIRU (SOUTHERN BLUE FIN TUNA)
}

\author{
Victor P. H. Nikijuluw \\ Peneliti pada Pusat Riset Perikanan Tangkap, Ancol-Jakarta \\ Teregristrasi I tanggal: 6 Pebruari 2007; Diterima setelah perbaikan tanggal: 26 Maret 2008; \\ Disetujui terbit tanggal: 25 April 2008
}

\begin{abstract}
ABSTRAK
Tuna sirip biru adalah ikan berharga tinggi yang semakin kurang populasi nya akibat penangkapan secara ekstensif. Ikan ini hanya terdapat di Samudera Hindia. Daerah pemijahannya diduga di perairan selatan Bali dan Lombok. Pengelolaan konservasi ikan ini dilakukan oleh Commission for the Conservation of Southern Blue Fin Tuna, di mana Indonesia adalah salah satu anggotanya. Kehadiran Indonesia sebagai anggota menuntut Indonesia untuk ikut melakukan konservasi terhadap spesies ini. Namun, Indonesia juga patut mengembangkan perikanan dan perdagangan spesies ini bagi kepentingan nasional.
\end{abstract}

\section{KATA KUNCI: Samudera Hindia, tuna sirip biru, Conservation of Southern Blue Fin Tuna}

ABSTRACT: $\quad \begin{aligned} & \text { Southern blue fin tuna resource utilization. By: Victor } P . H . \\ & \text { Nikijuluw }\end{aligned}$

Southern blue fin tuna is a high priced fish which tends to have declining its population due to extensive fishing. The Indian Ocean is the species only habitat. Its spawning area is confined to the waters of southern coast of Bali and Lombok. The management conservation of the southern blue fin tuna is done by the Commission for the Conservation of Southern Blue Fin Tuna, where Indonesia as one of the members. The membership consequence is that Indonesia should undertake conservative actions and mechanisms for the species. Indonesia may develop fishery and trading of the species for its own benefit and interest.

\section{KEYWORDS: Indian Ocean, southern blue fin tuna, Conservation of Southern Blue Fin Tuna}

\section{PENDAHULUAN}

Tuna sirip biru selatan atau southern blue fin tuna dengan nama ilmiah Thunnus maccoyii adalah emas biru Samudera Hindia. Bagi masyarakat Jepang, southern blue fin tuna dinilai sebagai ikan terlezat di dunia. Karena itu, maka pasar utama southern blue fin tuna adalah Jepang. Nilai dagang southern blue fin tuna diperkirakan USD 6 milyar atau Rp. 6 trilyun. Karena itu, sumber daya southern blue fin tuna menarik untuk dieksploitasi. Akan tetapi, seperti sumber daya ikan lainnya, semakin tinggi tingkat eksploitasi, semakin besar peringatan untuk dikonservasi.

Jepang, Australia, dan Selandia Baru adalah negara yang sejak awal tahun 1960an memanfaatkan sumber daya southern blue fin tuna ini. Karena harganya yang tinggi di pasar Jepang (khusus di pasar Tsukiji, Tokyo), banyak negara lain misalnya Korea, Taiwan, Afrika Selatan, Filipina, dan Masyarakat Eropa ikut juga menangkap ikan ini. Indonesia, yang berbatasan langsung dengan Samudera Hindia secara tradisi sudah ikut juga memanfaatkan 
sumber daya ini. Meskipun begitu, boleh dikatakan bahwa sampai saat ini, Indonesia belum sepenuhnya mewujudkan komitmen untuk secara sistematis memanfaatkan southern blue fin tuna bagi pembangunan ekonomi perikanan, khususnya bagi kesejahteraan nelayan.

Tulisan kebijakan ini mencoba memberi pemahaman awal tentang southern blue fin tuna serta signifikasi bagi Indonesia. Pembahasan difokuskan pada bagaimana sumber daya southern blue fin tuna saat ini dikelola serta tanggung jawab internasional dalam memanfaatkan. Diharapkan melalui tulisan ini, policy makers dan policy advisers dapat memahami arah kebijakan yang perlu diambil yang pada akhirnya berguna bagi pembangunan ekonomi perikanan nasional.

\section{BIOEKOLOGI SOUTHERN BLUE FIN TUNA}

Southern blue fin tuna adalah ikan pelagis besar, perenang cepat, bermigrasi di Samudera Hindia pada kisaran $30-50^{\circ}$ LS. Habitat ikan ini memang khas, dan sebab itu tidak ditemui di tempat lainnya, kecuali di Samudera Hindia (Commission for the Conservation of Southern Blue Fin Tuna, 2006). Dalam jumlah yang sangat terbatas dan hanya pada waktu tertentu, southern blue fin tuna juga bermigrasi atau mampir di bagian timur Samudera Pasifik Selatan. Southern blue fin tuna juga hidup di laut utara dan dibudidayakan secara intensif di Laut Meditteranean. Namun, spesies yang di utara dan Samudera Hindia sangat berbeda dan sejauh ini belum ada bukti ilmiah bahwa saling berhubungan.

Secara berkala, pada periode tertentu, southern blue fin tuna berupaya ke perairan Indonesia untuk memijah. Bukti-bukti ilmiah menunjukkan bahwa sejauh ini perairan selatan Jawa Timur adalah satu-satunya tempat southern blue fin tuna memijah. Karena itu, southern blue fin tuna berpeluang tertangkap di perairan Indonesia dalam ukuran kecil atau dalam kondisi matang gonad. Satu-satunya daerah pemijahan (spawning ground) ini juga menunjukkan keberadaan penting kepulauan Indonesia dalam siklus hidup ikan ini serta penting pelibatan Indonesia dalam manajemen sumberdaya. Migrasi southern blue fin tuna untuk memijah di perairan selatan Jawa Timur karena memang suhu dan kondisi perairan cocok untuk siklus biologi tersebut.

Southern blue fin tuna dapat hidup mencapai usia 40 tahun. Panjang dapat mencapai lebih dari $2 \mathrm{~m}$ dengan bobot sekitar $200 \mathrm{~kg}$. Belum ada bukti ilmiah atau kepastian tentang usia di mana ikan ini menjadi dewasa. Karena itu, aspek ini terus diteliti. Data yang ada sejauh ini mengatakan bahwa southern blue fin tuna dewasa berukuran $1,5 \mathrm{~m}$ dengan usia 8 tahun. Setiap southern blue fin tuna dewasa berkelamin perempuan dapat menghasilkan jutan telur pada setiap periode pemijahan.

Pemijahan southern blue fin tuna di perairan selatan Jawa Timur berlangsung dari bulan September-April. Itu sebabnya, pada periode ini southern blue fin tuna banyak ditangkap oleh nelayan Indonesia (Andamari et al., 2005). Setelah memijah, juvenil bermigrasi ke selatan ke pantai barat benua Australia. Selama bulan-bulan musim panas (bulan Desember-April), southern blue fin tuna cenderung bergerombol di permukaan perairan pantai selatan Australia. Pada musim dingin, southern blue fin tuna tinggal di perairan laut dalam. Setelah mencapai usia 5 tahun, southern blue fin tuna jarang ditemukan di perairan permukaan. Ini berarti lebih senang hidup di laut yang lebih dalam. 
Beberapa aspek bioekologi tentang southern blue fin tuna adalah:

1. Berenang dengan kecepatan rata-rata 2$3 \mathrm{~km}$ per jam.

2. Laju pertumbuhan sampai usia 3 tahun adalah 1,5 cm per bulan. Data lain menunjukkan bahwa pertumbuhan southern blue fin tuna lebih cepat pada periode setelah tahun 1980-an dibandingkan periode sebelumnya. Tentang hal ini, belum ada penjelasan penyebabnya.

3. Cenderung mudah bertoleransi dengan suhu air karena sistem pernapasan yang berkembang serta suhu badan yang lebih tinggi dari suhu air.

4. Dapat hidup pada kedalaman air di atas $500 \mathrm{~m}$.

\section{STOK SOUTHERN BLUE FIN TUNA}

Sudah disinggung bahwa produksi southern blue fin tuna jauh menurun pada tahun 2000-an dibandingkan dengan tahun 1960-an. Hal ini memberi indikasi bahwa stok southern blue fin tuna cenderung telah dieksploitasi secara berlebihan. Secara lebih pasti, memang sulit untuk menduga potensi stok southern blue fin tuna karena ikan ini memiliki habitat yang luas, sifatnya yang bermigrasi jauh, dan hidupnya di laut dalam. Namun demikian, dari hasil kajian Scientific Committee Commission for the Conservation of Southern Blue Fin Tuna pada tahun 2006, informasi berikut ini diperoleh sebagai indikator stok southern blue fin tuna:

1. Rekruitmen pada tahun 2000 dan 2001 sangat buruk statusnya, bahkan jauh lebih rendah dari rekruitmen tahun 19941998.

2. Sebaran ukuran southern blue fin tuna yang tertangkap oleh long line Jepang dan Selandia Baru menunjukkan bahwa ikan ukuran kecil semakin banyak tertangkap.
3. Survei udara dan tempat pendaratan menunjukkan bahwa jumlah rekruitmennya lebih kecil (rendah) dibandingkan pada tahun 1994-1998.

4. Umur ikan yang tertangkap semakin mudah, yaitu pada modus (mode) 3 dan 4 tahun.

Berdasarkan monitoring data pendaratan southern blue fin tuna selama 10 tahun terakhir pada Stasiun Monitoring Tuna Benoa, Pusat Riset Perikanan Tangkap, Badan Riset Kelautan dan Perikanan, diperoleh indikator berikut yang dapat digunakan untuk menunjukkan status sumber daya southern blue fin tuna (Proctor et al., 2003; 2006):

1. Trend produksi southern blue fin tuna yang cenderung menurun. Produksinya tertinggi dicapai pada kuartal pertama tahun 2005, kemudian menurun jauh dan sedikit naik pada kuartal terakhir 2005. Sesudah itu, trend produksinya menurun secara nyata.

2. Ukuran ikan southern blue fin tuna yang semakin kecil, dari modus 1,8-2,0 m pada tahun 1997 menjadi 1,60-1,7 m pada tahun 2004.

3. Usia ikan southern blue fin tuna yang semakin mudah, dari modus 20 tahun pada tahun 1995 menjadi modus 12 tahun pada tahun 2003.

4. Lahan penangkapannya yang semakin jauh, ikan semakin sulit dicari. Kedua hal ini mengindikasikan bahwa sumberdaya southern blue fin tuna cenderung mengalami penurunan (deplesi).

\section{MANAJEMEN KONSERVASI DAN PEMANFAATAN SOUTHERN BLUE FIN TUNA}

Southern blue fin tuna ditangkap dengan intesitas tinggi pada awal tahun 1960-an dengan jumlah pendaratan 80.000 ton per 
tahun. Akibat penangkapan yang cukup besar ini membuat berkurangnya jumlah ikan dewasa dan kejatuhan hasil tangkapan secara signifikan. Pada saat ini, produksi southern blue fin tuna dunia tidak melebihi 15.000 per tahun. Kajian yang dilakukan oleh Scientific Committee dari Commission for the Conservation of Southern Blue Fin Tuna menyimpulkan jumlah tangkapan yang diperbolehkan di bawah 14,925 ton yang akan mampu meningkatkan biomasa southern blue fin tuna melalui pemijahan (spawning) secara berkelanjutan.

Pada awal tahun 1980-an, southern blue fin tuna semakin sulit ditemukan. Suatu pertanda bahwa stok sumberdaya ini perlu dikelola serta langkah-langkah konservasi diperlukan. Pembatasan hasil tangkapan terasa diperlukan guna pemulihan stoknya. Manajemen penangkapan perlu dilaksanakan untuk mencegah kehancuran stok dan kepunahan southern blue fin tuna. Oleh sebab itu, negara-negara utama penangkapan southern blue fin tuna pada saat itu, yaitu Australia, Jepang, dan Selandia Baru menerapkan sistem kuota penangkapan yang sangat ketat dengan cara mereduksi jumlah armada penangkapan pada tahun 1985. Hal ini dilakukan sebagai upaya untuk membangun kembali keberlanjutan perikanan southern blue fin tuna.

Pada bulan Mei 1993, ketiga negara tersebut membentuk badan yang bernama Commission for the Conservation of Southern Blue Fin Tuna yang diikuti dengan langkah-langkah pengurangan upaya penangkapan oleh setiap negara secara voluntir. Markas Commission for the Conservation of Southern Blue Fin Tuna berkedudukan di Canbera (Commission for the Conservation of Southern Blue Fin Tuna, 1994).
Tujuan Commission for the Conservation of Southern Blue Fin Tuna adalah menjamin konservasi dan utilisasi perikanan southern blue fin tuna secara global melalui penerapan mekanisme manajamen sumberdaya serta pengaturan armada penangkapan. Commission for the Conservation of Southern Blue Fin Tuna juga melakukan berbagai flora internasional untuk semua pihak dan pemangku kepentingan dalam rangka membahas isu-isu yang berkaitan dengan sumberdaya southern blue fin tuna. Untuk mencapai tujuan ini, fungsi Commission for the Conservation of Southern Blue Fin Tuna sebagai berikut (Commission for the Conservation of Southern Blue Fin Tuna, 2001):

1. Menetapkan jumlah tangkapan yang diperbolehkan serta alokasi bagi setiap negara anggota Commission for the Conservation of Southern Blue Fin Tuna.

2. Mempertimbangkan dan menetapkan tindakan-tindakan manajemen untuk mencapai tujuan konservasi.

3. Melakukan dan mengkoordinir program penelitian yang bertujuan untuk menyediakan informasi untuk mendukung keputusan manajamen sumberdaya. Penelitian ini dapat dilakukan oleh masing-masing negara anggota atau dikoordinir langsung oleh sektetariat Commission for the Conservation of Southern Blue Fin Tuna.

4. Mengambil keputusan untuk mendukung dan mengimplementasikan manajemen perikanan.

5. Menyediakan forum diskusi tentang isuisu yang relevan dengan tujuan Commission for the Conservation of Southern Blue Fin Tuna.

6. Mengkoordinir kegiatan negara anggota yang berkaitan dengan perikanan Commission for the Conservation of Southern Blue Fin Tuna. 
7. Mengembangkan kegiatan yang berkaitan dengan konservasi spesiesspesies yang secara biologi berhubungan dengan southern blue fin tuna serta hasil tangkapan sampingan (bycatch).

8. Mendorong negara-negara lainnya berpartisipasi dalam manajemen southern blue fin tuna sebagai anggota, non cooperating members, atau observers.

9. Melakukan kerja sama serta membangun hubungan dengan organisasi lainnya yang mengelola perikanan tuna di perairan yang merupakan habitat southern blue fin tuna.

Meskipun Commission for the Conservation of Southern Blue Fin Tuna sudah terbentuk, namun upaya-upaya konservasi sumberdaya belum menunjukkan hasil yang signifikan karena selain ketiga negara yang memprakarsai pembentukan, adanya negara lain yang juga ikut menangkap southern blue fin tuna. Oleh karena itu, maka keanggotaan Commission for the Conservation of Southern Blue Fin Tuna dikembangkan untuk mencakup negara-negara lainnya yang belum merupakan anggota.

Pada bulan Oktober 2001, Korea Selatan bergabung sebagai anggota. Pada bulan Agustus 2002, asosiasi perikanan Taiwan bergabung pula sebagai anggota. Sementara itu, Philipina, Afrika Selatan, dan masyarakat Eropa sudah bergabung sebagai negara-negara cooperarting non members masing-masing sejak bulan Agustus 2004, 2006, dan Oktober 2006. Status ini merupakan transisi untuk menjadi anggota penuh pada Commission for the Conservation of Southern Blue Fin Tuna.

Lalu bagaimana dengan Indonesia yang letak geografisnya persis di batas Samudera
Hindia dan perairan pantai yang merupakan daerah asuhan (spawning ground) bagi southern blue fin tuna? bahwa sekarang ini, Indonesia telah menjadi anggota penuh, merubah statusnya dari cooperating non members yang dijalani selama beberapa tahun. Sebagai anggota penuh, Indonesia memiliki hak untuk memanfaatkan sumberdaya southern blue fin tuna serta dapat menjual ke pasar internasional dengan tanpa kendala. Namun, di sisi lain, Indonesia juga berkewajiban menjaga keberlanjutan sumberdaya ini. Penelitian dilakukan Indonesia secara sistematis. Rekomendasi sistem pengeloaan southern blue fin tuna perlu ikut dirumuskan Indonesia. Demikian pula, Indonesia wajib menyampaikan data tentang southern blue fin tuna secara rutin, sekali dalam satu bulan, menghadiri berbagai sidang komisi, baik dalam aspek penelitian, kepatuhan akan aturan dan regulasi, ataupun dalam administrasi dan finansial komisi.

\section{FLAG OF CONVENIENCE}

Dalam beberapa tahun terakhir ini, southern blue fin tuna ditangkap secara signifikan oleh kapal perikanan dengan flag of convenience. Hal ini menjadi isu dan keprihatinan Commission for the Conservation of Southern Blue Fin Tuna, karena apa yang dilakukan oleh kapal-kapal seperti ini ternyata mengganggu keinginan Commission for the Conservation of Southern Blue Fin Tuna untuk mewujudkan perikanan yang berkelanjutan. Sejauh ini, Commission for the Conservation of Southern Blue Fin Tuna telah berusaha untuk dapat bekerjasama dengan negaranegara pemilik kapal flag of convenience. Commission for the Conservation of Southern Blue Fin Tuna juga telah memutuskan bahwa bila kerja sama tidak dapat diwujudkan, maka tindakan tegas, termasuk pembatasan perdagangan seperti embargo, akan dilakukan sesuai dengan 
rencana aksi Commission for the Conservation of Southern Blue Fin Tuna.

\section{SKIM INFORMASI PERDAGANGAN}

Commission for the Conservation of Southern Blue Fin Tuna telah menetapkan skim informasi perdagangan sejak bulan Juni 2000. Melalui skim informasi perdagangan, monitoring perdagangan internasional southern blue fin tuna dilakukan sehingga dengan pasti dapat diketahui produsen southern blue fin tuna baik per negara maupun perusahaan. Skim informasi perdagangan dilaksanakan pula untuk mencegah perikanan illegal, unreported, and unregulated dengan secara sederhana mencegah produk yang dihasilkannya melalui praktik perikanan illegal, unreported, and unregulated masuk ke pasar southern blue fin tuna yang memang sangat terbatas dan dengan mudah diproteksi.

Intisari skim informasi perdagangan adalah negara anggota dan cooperating non members untuk melakukan kegiatan ekspor dengan kewajiban memiliki dokumentasi statistik yang jelas. Dengan kata lain, ekspor hanya dapat dilaksanakan bila negara eksportir sudah memenuhi kewajiban untuk menyediakan statistik tentang perikanan southern blue fin tuna di negara.

Dokumen statistik yang dimaksud dikeluarkan oleh otoritas yang berwenang di masing-masing negara. Di Indonesia, lembaga yang dimaksud adalah Departemen Kelautan dan Perikanan. Dokumen statistik tersebut secara rinci menerangkan tentang nama kapal, tipe alat tangkap, lahan penangkapan, dan tanggal operasi penangkapan. Dokumen statistik ini dikirim ke sekretariat Commission for the Conservation of Southern Blue Fin Tuna yang nantinya digunakan untuk kepentingan data dasar (data base) bagi kegiatan monitoring hasil tangkapan dan perdagangan.

Dengan berlakunya skim informasi perdagangan, maka dapat dikatakan bahwa Commission for the Conservation of Southern Blue Fin Tuna sudah menerapkan konsep traceability (ketelusuran) pada proses produksi perikanan. Kesalahan data yang dikatakan, baik tidak sengaja apalagi secara sengaja, akan memberikan dampak yang merugikan bagi negara produsen atau pengekspor.

\section{KUOTA TAHUN 2007-2009}

Dalam sidang tahunan Commission for the Conservation of Southern Blue Fin Tuna ke-13 pada bulan Oktober 2006, kuota penangkapan dan perdagangan untuk tahun 2007-2011 ditetapkan. Penetapan kuota ini mempertimbangkan kinerja setiap negara anggota dan cooperating non members Commission for the Conservation of Southern Blue Fin Tuna serta jumlah tangkapan yang diperbolehkan berdasarkan pada analisis keberadaan stoknya. Keputusan sidang tahunan tersebut yaitu jumlah tangkapan yang diperbolehkan pada tahun 2007-2011 adalah 11,810 ton. Kuota ini bisa direvisi bila sebelum akhir tahun 2009 hal-hal yang khusus terjadi atas sumber daya southern blue fin tuna.

Alokasi jumlah tangkapan yang diperbolehkan bagi negara anggota, cooperating non members, dan observer sebagai berikut:

\section{Cooperating non members}

1. Philipina: 45 ton sampai akhir tahun 2007.

2. Afrika Selatan: 40 ton sampai akhir tahun 2007.

3. Masyarakat Eropa: 10 ton sampai akhir tahun 2007. 
Dengan adanya alokasi jumlah tangkapan yang diperbolehkan ini, maka Indonesia memiliki kesempatan lagi untuk memasarkan hasil tangkapan southern blue fin tuna ke pasar internasional. Kebijakan ini sungguh merupakan suatu berkat bagi Indonesia karena sebelumnya, sejak tanggal 1 Juli 2005, seluruh produksi southern blue fin tuna oleh nelayan Indonesia dikenai embargo di pasar internasional. Dengan diberlakukannya kuota yang baru ini, Indonesia kembali dapat menjual produk di pasar Jepang. Namun demikian, sebelum hal tersebut dapat direalisasikan, Indonesia perlu menyampaikan dokumen statistik kepada sekretariat Commission for the Conservation of Southern Blue Fin Tuna seperti yang disyaratkan Commission for the Conservation of Southern Blue Fin Tuna menurut skim informasi perdagangan.

\section{INDUSTRI PERIKANAN SOUTHERN BLUE FIN TUNA INDONESIA}

Industri perikanan southern blue fin tuna Indonesia pada umumnya berpusat di Benoa, Bali. Saat ini, terdapat sekitar 700 kapal long line yang menangkap ikan tuna yang terdiri atas jenis tuna sirip kuning, tuna mata besar, dan southern blue fin tuna. Dari jumlah armada ini, sekitar 590 kapal yang aktif beroperasi. Sekitar 110 kapal tidak beroperasi karena berbagai alasan. Jumlah tenaga kerja di laut (kru kapal) yang terserap adalah sekitar 1.050 orang. Dengan jumlah tenaga kerja di darat yang sama jumlahnya, maka industri perikanan southern blue fin tuna di Benoa, Bali menampung sekitar 2.100 tenaga kerja. Seluruh perusahaan tuna long line di Benoa, Bali ini bergabung dalam Asosiasi Tuna Long Line Indonesia.

Sasaran penangkapannya adalah semua jenis tuna, dengan komposisi hasil tangkapan didominasi oleh tuna sirip kuning, diikuti oleh tuna mata besar, dan southern blue fin tuna. Karena southern blue fin tuna belum merupakan sasaran penangkapan utama, maka produksi southern blue fin tuna memang relatif kecil dibandingkan dengan jenis ikan tuna lainnya. Selama 5 tahun terakhir, produksi rata-rata southern blue fin tuna di Benoa sekitar 700 ton per tahun. Data statistik juga menunjukkan hanya sekitar 10 perusahaan yang secara rutin menangkap southern blue fin tuna.

Penangkapan southern blue fin tuna dilakukan di Zona Ekonomi Ekslusif Indonesia. Namun demikian, banyak kapal yang beroperasi di lahan (fishing ground) yang berada di luar Zona Ekonomi Ekslusif, bahkan jauh melampaui $30^{\circ}$ LS. Kehadiran kapal long line Indonesia di perairan laut dalam ini seringkali mengundang interpretasi ganda di kalangan anggota Commission for the Conservation of Southern Blue Fin Tuna dan anggota Indian Ocean Tuna Commission. Di satu sisi, sering kali kehadiran kapal-kapal Indonesia dinilai sebagai aktivitas perikanan illegal, unreported, and unregulated. Di sisi lain, kapal-kapal perikanan Indonesia ini tidak dinilai melakukan praktik illegal, unreported, and unregulated karena data tentang kapalkapal ini yang sudah didaftarkan dan didepositokan di sekreatriat Indian Ocean Tuna Commission. Interpretasi ganda seperti ini tidak akan terjadi apabila Indonesia adalah anggota penuh Commission for the Conservation of Southern Blue Fin Tuna maupun Indian Ocean Tuna Commission.

Karena jarak daerah penangkapan yang jauh dari pelabuhan Benoa, disertai dengan peralatan penanganan yang belum sempurna yang di atas kapal, maka southern blue fin tuna yang dihasilkan nelayan Indonesia tidak selalu berkualitas prima. Southern blue fin tuna selalu dijual dalam 
bentuk produk segar. Produk southern blue fin tuna beku hampir tidak dijumpai karena harganya yang memang sudah jauh lebih rendah. Namun, menghasilkan dan menjual produk segar adalah masalah lain bagi Indonesia karena faktor jarak yang jauh dari pangkalan Benoa serta kondisi fasilitas penanganan pasca panen yang tidak sempurna.

Akibat dari kualitas yang rendah, maka harga FOB southern blue fin tuna Indonesia berkisar USD 8-9 per kg. Harga rata-rata southern blue fin tuna di pasar Tsukiji Jepang adalah sekitar USD 20 per kg. Southern blue fin tuna dengan kualitas yang sangat baik dapat mencapai USD 100 per $\mathrm{kg}$. Dengan produksi dan harga yang berlaku, diperkirakan Indonesia meraih devisa USD 6,3 juta.

Di pasar Tsukiji Jepang, di mana lelang southern blue fin tuna dilakukan setiap hari, southern blue fin tuna yang berasal dari Indonesia mendapat giliran terakhir untuk dilelang. Karena itu, produk Indonesia ini ditempatkan di pojok bangsal pelelangan (auction hall). Selain ukurannya yang relatif lebih kecil, mutu southern blue fin tuna Indonesia juga memang relatif rendah. Hal ini yang membuat sehingga harga southern blue fin tuna Indonesia relatif lebih rendah dari yang berasal dari negara lain.

\section{REKOMENDASI KEBIJAKAN}

Perikanan southern blue fin tuna cukup signifikan secara ekonomis bagi Indonesia. Produksi yang dicapai Indonesia saat ini serta kuota yang dialokasikan memang relatif kecil. Dengan menjadi anggota Commission for the Conservation of Southern Blue Fin Tuna, patutnya Indonesia memperjuangkan penambahan kuota. Meskipun jumlah kuota cukup kecil, industri yang ada sudah mampu menghasilkan devisa dan menyediakan lapangan kerja yang cukup signifikan bagi ekonomi lokal. Kontribusi ekonomi ini dapat lebih besar, setidaknya nilai devisa dapat digandakan, bila harga southern blue fin tuna Indonesia tidak berbeda dengan harga southern blue fin tuna dari negara lain. Namun, untuk dapat mencapai tahap itu, perlu ada perbaikan dalam penanganan, baik di kapal, pelabuhan pendaratan, maupun pelabuhan ekspor. Perbaikan-perbaikan ini dapat dilakukan sendiri oleh swasta. Namun demikian, pemerintah patut mendorong agar perbaikan proses penanganan (handling) pasca panen, pendaratan, dan persiapan pengiriman produk melalui bandar udara dapat dilakukan dengan lebih baik dan lancar.

Secara biologi, produksi southern blue fin tuna total dalam tahun-tahun terakhir ini memang cenderung konstan pada tingkat sekitar 11,000 ton per tahun. Hal ini karena skim kuota perdagangan yang diterapkan Commission for the Conservation of Southern Blue Fin Tuna dalam rangka mewujudkan keberlanjutan perikanan ini. Meskipun, secara produksi total dunia sulit ditingkatkan, namun produksi southern blue fin tuna Indonesia sangat mungkin ditingkatkan dari posisi saat ini sekitar 700 ton (sekitar 6,5\% pangsa produksi dunia).

Sehubungan dengan keikutsertaan Indonesia sebagai anggota Commission for the Conservation of Southern Blue Fin Tuna, Indonesia yang dalam hal ini Departemen Kelautan dan Perikanan perlu menetapkan pejabat penghubung (liaison) yang bertugas melakukan hubungan dan komunikasi secara intensif dengan sekretariat Commission for the Conservation of Southern Blue Fin Tuna di Canbera. Menurut rules and procedures Commission for the Conservation of Southern Blue Fin Tuna, pejabat penghubung didampingi oleh expert (tenaga ahli) dan adviser (penasehat). Berkaitan dengan itu, pemerintah dalam hal 
ini Departemen Kelautan dan Perikanan patut membentuk tim khusus atau kelompok kerja yang memang diberi tugas khusus.

Sebagai tindak lanjut dari kuota southern blue fin tuna yang diberikan pada Indonesia selama tahun 2007, pemerintah dalam hal ini Departemen Kelautan dan Perikanan patut menindaklanjutinya dalam dua hal penting, yaitu membagi kuota tersebut di antara perusahaan-perusahaan yang ada, dan memberitahukan kepada sekretariat Commission for the Conservation of Southern Blue Fin Tuna tentang pembagian kuota ini, serta cara dan metode mencapai dalam rangka traceability. Dalam wujud yang lebih nyata, pemerintah patut berupaya agar kuota Indonesia dapat ditingkatkan, paling tidak sama dengan kuota yang diberi sekarang pada Australia dan Jepang. Pemerintah juga patut mengajukan program riset dan pengkajian pada Commission for the Conservation of Southern Blue Fin Tuna dalam rangka konservasi dan perlindungan daerah pemijahan.

Fakta ilmiah bahwa daerah pemijahan (spawning ground) Southern Blue Fin Tuna di perairan pantai selatan Jawa Timur dapat dijadikan kekuatan tawar menawar Indonesia di Commission for the Conservation of Southern Blue Fin Tuna. Negosiasi dan diplomasi Indonesia di Commission for the Conservation of Southern Blue Fin Tuna patut mengungkapkan dan menggunakan fakta ini sebagai senjata untuk meningkatan posisi tawar Indonesia.

\section{DAFTAR PUSTAKA}

Andamari, R., T. L. O. Davis, B. Iskandar, D. Retnowati, M. Herrera, C. H. Proctor, \& S. Fujiwara. The catch of southern blue fin tuna by the Indonesian longline fishery operating out of Benoa, Bali in 2004. Paper prepared for the Commission for the Conservation of Southern Blue Fin Tuna $6^{\text {th }}$ Meeting of the Stock Assessment Group and the $10^{\text {th }}$ Meeting of the Extended Scientific Committee (ESC10). 29 August-3 September, and 5-8 September 2005. Taiwan.

Commission for the Conservation of Southern Blue Fin Tuna. 1994. Text of Convention for the Conservation of Southern Bluefin Tuna.

Commission for the Conservation of Southern Blue Fin Tuna. 2001. Rules of Procedure of the Commission for the Conservation of Southern Blue Fin Tuna.

Commission for the Conservation of Southern Blue Fin Tuna. 2006. Reports on the Special Meeting of the Commission. 18-19 July. Canberra Australia.

Proctor, C. H., T. L. Davis., \& R. Andamari. 2003. Indonesia's monitoring and reporting systems for tuna landings at port of Benoa. Paper Prepared for the Commission for the Conservation of Southern Blue Fin Tuna Indonesian Catch Monitoring Review. 10-11 April 2003. Queenstown. New Zeland.

Proctor, C., R. Andamari, D. Retnowati, M. Herrera, F Poisson, S. Fujiwara, \& T. L. Davis. 2006. The catch of southern blue fin tuna by the Indonesian long line fishery operating out of Benoa, Bali in 2005. Paper prepared for the Commission for the Conservation of Southern Blue Fin Tuna $7^{\text {th }}$ Meeting of the Stock Assessment Group and the $11^{\text {th }}$ Meeting of the Extended Scientific Committee, 4-11 September, and 12-15 September 2006. Tokyo. Japan. 